\section{Supplemental Carbon Dioxide and Light Improved Tomato and Pepper Seedling Growth and Yield}

\author{
Alejandro Fierro, Nicolas Tremblay', and André Gosselin \\ Department of Phytology, Faculty of Agriculture and Food, Laval University, \\ Sainte-Fey, Que. G1K 7P4, Canada
}

Additional index words. Lycopersicon esculentum, Capsicum annuum, seedling conditioning

\begin{abstract}
The experiment was conducted to determine the effects of $\mathrm{CO}$, enrichment $(900$ $\left.\mu \mathrm{l} \cdot \mathrm{liter}^{-1}, 8 \mathrm{hours} / \mathrm{day}\right)$ in combination with supplementary lighting of $100 \mu \mathrm{mol} \cdot \mathrm{s}^{-1} \cdot \mathrm{m}^{-2}(16-$ $h$ photoperiod) on tomato (Lycopersicon esculentum Mill.) and sweet pepper (Capsicum annuum L.) seedling growth in the greenhouse and subsequent yield in the field. Enrichment with $\mathrm{CO}_{2}$ and supplementary lighting for $\approx 3$ weeks before transplanting increased accumulation of dry matter in shoots by $\approx \mathbf{5 0 \%}$ compared with the control, while root dry weight increased $49 \%$ for tomato and 6270 for pepper. Early yields increased by $=1570$ and $11 \%$ for tomato and pepper, respectively.
\end{abstract}

Among the most important factors affecting seedling growth and development that can be optimized in a greenhouse are ambient $\mathrm{CO}_{2}$ concentration and light energy. Seedlings grow more quickly at high $\mathrm{CO}_{2}$ concentrations, and a value of $1000 \mu \mathrm{l} \cdot$ liter $^{-1}$ seems to be optimal (Madsen, 1973; Porter and Grodzinksi, 1985). Morgan (1971) concluded that for tomato seedlings, early yields depended on rapid accumulation of dry matter.

In northern regions, the production of transplants in the spring is limited by poor light conditions. Seedlings grown under low light reveal photosynthetic characteristics common to shade plants and are unable to use the relatively intense light that prevails in the field efficiently (Bjorkman, 1981). There is an interaction between supplementary lighting and $\mathrm{CO}_{2}$ enrichment. According to Mortensen and Moe (1983), the largest increase in growth rate achieved with $\mathrm{CO}_{2}$ enrichment is obtained with the highest photosynthetic photon flux density (PPFD). They further suggest that a high $\mathrm{CO}_{2}$ concentration may partially compensate for an insufficient PPFD.

Differences in seedling growth obtained up to the transplanting stage with $\mathrm{CO}_{2}$ and light treatments may influence yields. When applied separately, $\mathrm{CO}_{2}$ enrichment and supplementary lighting at the seedling stage can increase early yields of greenhouse tomatoes (Boivin et al., 1986; Morgan, 1986).

The objective of this study was to determine the effects of combined $\mathrm{CO}_{2}$ and supplementary lighting on the growth and subse-

Received for publication 22 July 1993. Accepted for publication 11 Aug. 1993. We thank Josée Charbonneau for her help. The cost of publishing this paper was defrayed in part by the payment of page charges. Under postal regulations, this paper therefore must be hereby marked advertisement solely to indicate this fact.

To whom reprint requests should be addressed. Current address: Agriculture Canada Research Station, 430 Gouin Blvd., Saint-Jean-sur-Richelieu, Que. J3B 3E6, Canada. quent fruit yields of tomato and pepper seedlings grown in the field.

\section{Materials and Methods}

Plant material and cultivation

'Springset' tomato and 'Bell Boy' pepper were sown on 25 Apr. and 19 May 1989, respectively, in multicellular polystyrene trays (\#50 Sutton plug trays; Kord Products, Bramalea, Ont.) (365 seedlings $/ \mathrm{m}^{2}$ ) filled with a peat-based seedling mixture (Pro-Mix; Tourbières Premier Ltée, Riviere-du-Loup, Que.). Seeds were covered with a thin layer of vermiculite, and the trays were placed on tables in four identical greenhouse compartGermination in the compartments was at $27 \pm$ 2C. During subsequent growth, the ventilation set point was $18 \mathrm{C}$.

Carbon dioxide and light were supplemented from the time the cotyledons completely unfolded. The seedlings then were fertigated every morning and evening until partial drainage occurred. They were irrigated with tap water at noon, if necessary. The nutrient solution concentration was increased as the seedlings developed. During the first week, it included (in ppm) $100 \mathrm{~N}, 50 \mathrm{P}, 100 \mathrm{~K}$, $22 \mathrm{Ca}, 6 \mathrm{Mg}, 0.4 \mathrm{Fe}, 0.3 \mathrm{Mn}, 0.2 \mathrm{CU}, 0.2 \mathrm{~B}, 0.1$ $\mathrm{Zn}$, and $0.06 \mathrm{Mo}$. The mineral concentrations were doubled and tripled in the second and third week, respectively. The respective nutrient solution $\mathrm{pH}$ was $6.4,6.5$, and 6.2 ; the respective electrical conductivity was $1.0,1.51$, and $2.26 \mathrm{mS} \cdot \mathrm{cm}^{-1}$.

Tomato and pepper plants were transferred to the field 29 and 32 days and 37 and 40 days after sowing, respectively. The experimental plots were located at Laval Univ., where the was done manually and seedlings were watered immediately with a $10 \mathrm{~N}-52 \mathrm{P}-10 \mathrm{~K}(500$ ppm N) transplanting solution. The plots were sprinkler-irrigated as indicated by tensiomments $\left(24 \mathrm{~m}^{2}\right)$ at Laval Univ., Quebec City. soil is a St. Nicolas schist loam. Transplanting eters with a $30-\mathrm{kPa}$ threshold. Cultivation was conducted according to commercial practices (Conseil des Productions Végétales du Québec, 1982).

\section{Treatments}

The light treatments were as follows: 1) natural light only and 2) natural light supplemented with $100 \mu \mathrm{mol} \cdot \mathrm{s}^{-1} \cdot \mathrm{m}^{-2}$ photosynthetically active radiation (PAR). The supplementary lighting was provided by $400-\mathrm{W}$ high-pressure sodium lamps (HPS Solux Lumiponic, no. 400-SO-SHP-120; Lumiponic, SaintLaurent, Que.), and the PPFD was measured with an LI- 185 photometer equipped with an LI-190SB quantum sensor (LI-COR, Lincoln, Neb.). The lamps operated between 0200 and $1000 \mathrm{HR}$, to extend the photoperiod to $16 \mathrm{~h}$.

The CO, treatments consisted of 1) ambient in the greenhouse and 2) $900 \pm 100$ $\mu l \cdot l i t e r^{-1}$ from 0200 to 1000 HR. This period was chosen because the lower temperatures limited ventilation requirements and kept $\mathrm{CO}_{2}$ concentrations at the desired levels. Compressed CO, (Liquid Air Canada, Montréal, Que.) was used. Carbon dioxide concentration was maintained with an infrared analyzer (no. APBA $251 \mathrm{E} \mathrm{CO}_{2}$ monitor; Priva Computers, De Lier, Netherlands) and recorded by a computerized datalogging system.

\section{Design of experiment and growth variables}

The four greenhouse compartments formed two experimental blocks. Each block consisted of two main plots corresponding to the $\mathrm{CO}_{2}$ treatments. Within each main plot were the light treatments, distributed randomly in subplots and repeated four times for a total of 32 subplots. The subplots were separated by white polyethylene opaque curtains that were opened between 1000 and 1800 HR. In each subplot, there were four multicellular trays, one per species and per sowing, containing 50 seedlings each (experimental unit). The design in the greenhouse was a split-plot with $\mathrm{CO}_{2}$ concentration in the main plots and lighting treatments in the subplots. The two sowings were considered repeated measurements (Little and Hills, 1978). Statistical analysis was performed using SAS software (SAS Institute, Cary, N.C.). On the eve of the transplant day, eight sample plants were picked randomly from the center of each multicellular tray to measure root and shoot dry weights (48 $\mathrm{h}$ at 70C).

In the field, the split-plot design included eight replications. Planting dates were main plots, and the subplots contained the $\mathrm{CO}_{2}$ and light treatments applied previously in the greenhouse. The experimental unit consisted of a row of eight plants with a guard plant at each end. A guard row was between each main plot. The tomato and pepper plants were planted $0.30 \mathrm{~m}$ apart within rows, with 1.5 and $1 \mathrm{~m}$ between rows, respectively. The plots were harvested by hand once each week. Early yields consisted of the first two tomato harvests, but only the first pepper harvest. At each 
harvest, marketable and "all categories" (marketable fruits + culls) yields were measured. Defect-free tomato fruit were considered marketable. Pepper fruit $>5$ and $7 \mathrm{~cm}$ in diameter were considered marketable.

Homogeneity of variance among treatments was verified for all variables using the Bartlett test with $P \leq 0.01$.

\section{Results and Discussion}

\section{Seedling growth}

Carbon dioxide enrichment increased shoot dry weight of both species for both planting dates, but only root dry weight for the second sowing, with a $12 \%$ increase for tomato and $11 \%$ for pepper (Table 1). A more abundant root system would likely encourage rapid reestablishment after transplanting (Weston and Zandstra, 1986), as these young plants would have better access to soil water and nutrients. The second sowing showed a greater response to $\mathrm{CO}_{2}$ enrichment than the first, possibly because treatments were applied for three more days on the second sowing, which also benefited from better natural light conditions. Under our experimental conditions, the effect of $\mathrm{CO}_{2}$ enrichment was less than previously experienced (Porter and Grodzinski, 1985). There are two probable reasons for the mitigated $\mathrm{CO}_{2}$ effect: 1) $\mathrm{CO}_{2}$ enrichment was applied only during half of the photoperiod and 2 ) the ventilation set point was $18 \mathrm{C}$, resulting in frequent ventilation and drops in $\mathrm{CO}_{2}$ concentration, even though $\mathrm{CO}_{2}$ injection was maintained during ventilation.

Supplementary lighting increased shoot dry weight $44 \%$ in peppers and $32 \%$ in tomatoes (Table 1). Shoot dry weight of tomato seedlings with $\mathrm{CO}$, and supplementary lighting increased by $33 \%$ and $66 \%$ in the first and second sowings, respectively, compared with control plants. This increase was $42 \%$ for the first pepper seedling sowing and $67 \%$ for the second. Mortensen and Moe (1983) obtained maximum growth of young chrysanthemum [Dendranthema $\times$ grandiflorum (Ramat.) Kitamura] seedlings with a $\mathrm{CO}_{2}$-enriched atmosphere and high PPFD. Tomato and pepper seedlings accumulated $37 \%$ and $49 \%$ more dry matter, respectively, in their roots under supplementary lighting (average of two sowings) (Table 1). The results are similar for lettuce (Lactuca sativa L.), broccoli (Brassica oleracea L. Botrytis Group), and tomato seedlings given supplementary lighting (Masson et al., 1991a).

Carbon dioxide enrichment and supplementary lighting interacted positively on seedling root dry weight, with $49 \%$ and $62 \%$ increases for tomato and pepper, respectively. Desjardins et al. (1990) reported a positive $\mathrm{CO}_{2}$ enrichment $\times$ supplementary lighting interaction on shoot and root dry weights of asparagus (Asparagus officinalisL.)transplants.

\section{Yield}

Tomato. Higher early and cumulative yields were observed for all-categories fruit when seedlings were enriched with $\mathrm{CO}_{2}$ (Table 2). According to Morgan (1986), the increase in early yields of tomato seedlings enriched with $\mathrm{CO}_{2}$ is due in part to accelerated anthesis and fruit maturation. Carbon dioxide enrichment increased the cumulative yields of marketable fruit by $7 \%$ for the second planting. The percentage of marketable fruit was not affected by $\mathrm{CO}$, treatments.

The effect of supplementary lighting lasted through the first two harvests. Early yields in all-categories fruit increased by $\approx 10 \%$ for both first and second plantings (Table 2). Under similar conditions, Masson et al. (199 lb) obtained greater effects of lighting than those reported here, although the differences obtained in accumulated dry weight at the time of transplanting were similar. The cumulative yields were not changed by adding artificial light, which agrees with Masson et al.'s (1991b) results.

When comparing control seedlings planted first with those that received simultaneous $\mathrm{CO}$, and light treatments, early yields increased $15 \%$ and $22 \%$ for marketable fruit and total fruit, respectively (Table 2). These increases were $12 \%$ and $10 \%$ for the second planting. The $\mathrm{CO}_{2} \times$ lighting interaction did not affect the cumulative yields of either of the two plantings. All yield increases measured were due to a greater number of fruit.

Pepper. Based on the analysis of variance, there was no significant difference between treatments. However, $\mathrm{CO}^{2}$ enrichment tended to improve early yields of marketable fruit and all-categories yields (7\%) for the first planting (Table 3). As observed for tomato seedlings, supplementary lighting interacted with $\mathrm{CO}_{2}$ enrichment to increase early yields by 1190 over control. The second planting was unproductive after a heavy flower drop and almost no fruit set because of extremely high temperatures and water stress.

In summary, combined $\mathrm{CO}$, enrichment

Table 1. Effects of $\mathrm{CO}_{2}$ enrichment and $100 \mu \mathrm{mol} \cdot \mathrm{s}^{-1} \cdot \mathrm{m}^{-2}$ photosynthetically active radiation supplementary lighting during plant growth on shoot and root dry weight of tomato and pepper transplants for two sowings.

\begin{tabular}{|c|c|c|c|c|c|}
\hline \multirow{2}{*}{$\begin{array}{l}\mathrm{CO}_{2} \\
\left(\mu \mathrm{l} \cdot \text { liter }{ }^{-1}\right)\end{array}$} & \multirow{2}{*}{$\begin{array}{c}\text { Supplementary } \\
\text { lighting }\end{array}$} & \multicolumn{2}{|c|}{$\begin{array}{c}\text { Tomato dry wt } \\
\text { (mg/plant) }\end{array}$} & \multicolumn{2}{|c|}{$\begin{array}{c}\text { Pepper dry wt } \\
\text { (mg/plant) }\end{array}$} \\
\hline & & Shoot & Root & Shoot & Root \\
\hline \multicolumn{6}{|c|}{ First planting } \\
\hline \multirow[t]{2}{*}{900} & + & 544 & 46 & 486 & 33 \\
\hline & - & 411 & 32 & 349 & 24 \\
\hline \multirow[t]{3}{*}{350} & + & 500 & 44 & 473 & 34 \\
\hline & - & 410 & 32 & 342 & 23 \\
\hline & Second & & & & \\
\hline \multirow[t]{2}{*}{900} & + & 635 & 56 & 674 & 71 \\
\hline & - & 455 & 40 & 463 & 48 \\
\hline \multirow[t]{2}{*}{350} & + & 505 & 50 & 613 & 65 \\
\hline & - & 383 & 36 & 404 & 42 \\
\hline \multicolumn{6}{|l|}{ Significance } \\
\hline Lighting & & $* * *$ & $* * *$ & $* * *$ & $* * *$ \\
\hline Lighting $\times$ planting & & NS & NS & $* *$ & $* *$ \\
\hline $\mathrm{CO}_{2}^{\mathrm{z}}$ & & 17 & 3 & 21 & 2 \\
\hline
\end{tabular}

${ }^{2}$ Standard error of the means, because the $\mathrm{C}_{2}$ treatment could be run only twice.

ss $* *, * * *$ Nonsignificant or significant at $P \leq 0.01$ or 0.001 , respectively.

Table 2. Effects of $\mathrm{CO}_{2}$ enrichment and $100 \mu \mathrm{mol} \cdot \mathrm{s}^{-1} \cdot \mathrm{m}^{-2}$ photosynthetically active radiation supplementary lighting during plant growth on yield of tomatoes transplanted to the field for two plantings.

\begin{tabular}{|c|c|c|c|c|c|}
\hline \multirow{2}{*}{$\begin{array}{l}\mathrm{CO}_{2} \\
\left(\mu l \cdot \text { liter }^{-1}\right)\end{array}$} & \multirow{2}{*}{$\begin{array}{c}\text { Supplementary } \\
\text { lighting }\end{array}$} & \multicolumn{2}{|c|}{ Early yield $\left(\mathrm{t} \cdot \mathrm{ha}^{-1}\right)^{\mathrm{z}}$} & \multicolumn{2}{|c|}{ Cumulative yield $\left(\mathrm{t} \cdot h \mathrm{a}^{-1}\right)^{\mathrm{y}}$} \\
\hline & & Marketable & $\mathrm{All}^{\mathrm{x}}$ & Marketable & All \\
\hline \multicolumn{6}{|c|}{ First planting } \\
\hline \multirow[t]{2}{*}{900} & + & 10.6 & 27.5 & 21.8 & 72.8 \\
\hline & - & 9.2 & 23.0 & 24.1 & 73.3 \\
\hline \multirow[t]{2}{*}{350} & + & 9.0 & 22.7 & 26.7 & 74.7 \\
\hline & - & 9.2 & 22.5 & 23.5 & 68.4 \\
\hline \multicolumn{6}{|c|}{ Second planting } \\
\hline \multirow[t]{2}{*}{900} & + & 21.0 & 36.2 & 44.8 & 77.1 \\
\hline & - & 18.6 & 32.7 & 43.0 & 74.6 \\
\hline \multirow[t]{2}{*}{350} & + & 19.4 & 35.2 & 39.7 & 70.8 \\
\hline & - & 18.7 & 32.8 & 42.3 & 72.6 \\
\hline \multicolumn{6}{|l|}{ Significance } \\
\hline Lighting (L) & & NS & $*$ & NS & NS \\
\hline $\mathrm{CO}_{2}$ & & NS & * & NS & $*$ \\
\hline Planting (P) & & $* * *$ & $* * *$ & $* * *$ & NS \\
\hline $\mathrm{CO}_{2} \times \mathbf{P}$ & & NS & NS & $*$ & NS \\
\hline $\mathbf{L} \times \mathrm{CO}_{2} \times \mathbf{P}$ & & NS & NS & $*$ & NS \\
\hline
\end{tabular}

${ }^{2}$ First two harvests.

${ }^{y}$ Sum of six harvests.

${ }^{x}$ All categories confounded.

NS, *,***Nonsignificant or significant at $P \leq 0.05$ or 0.001 , respectively. 
Table 3. Effects of $\mathrm{CO}_{2}$ enrichment and $100 \mu \mathrm{mol} \cdot \mathrm{s}^{-1} \cdot \mathrm{m}^{-2}$ photosynthetically active radiation supplementary lighting during plant growth on yield of peppers transplanted to the field. Means of eight replications \pm standard error.

\begin{tabular}{|c|c|c|c|c|c|}
\hline \multirow{2}{*}{$\begin{array}{l}\mathrm{CO}_{2} \\
\left(\mu l \cdot \text { liter }^{-1}\right)\end{array}$} & \multirow{2}{*}{$\begin{array}{c}\text { Supplementary } \\
\text { lighting }\end{array}$} & \multicolumn{2}{|c|}{ Early yield $\left(\mathrm{t} \cdot h \mathrm{a}^{-1}\right)^{\mathrm{7}}$} & \multicolumn{2}{|c|}{ Cumulative yield $\left(\mathrm{t} \cdot \mathrm{h} \mathrm{a}^{-1}\right)^{\mathrm{y}}$} \\
\hline & & Marketable & $\mathrm{All}^{\mathrm{x}}$ & Marketable & All \\
\hline 900 & + & $4.7 \pm 0.9$ & $4.9 \pm 1.0$ & $17.7 \pm 1.1$ & $18.8 \pm 1.3$ \\
\hline & - & $4.3 \pm 0.3$ & $4.4 \pm 0.3$ & $16.5 \pm 1.1$ & $17.2 \pm 1.0$ \\
\hline 350 & + & $4.2 \pm 0.5$ & $4.3 \pm 0.5$ & $17.4 \pm 1.1$ & $18.8 \pm 1.3$ \\
\hline & - & $4.2 \pm 0.5$ & $4.4 \pm 0.5$ & $16.4 \pm 1.1$ & $17.5 \pm 1.2$ \\
\hline
\end{tabular}

${ }^{2}$ First harvest.

Sum of five harvests.

"All categories confounded.

and supplementary lighting in the greenhouse increased seedling shoot and root dry weights.

Early fruit yields were generally improved, although not significantly in all cases.

\section{Literature Cited}

Bjorkman, O. 1981. Responses to different quantum flux densities, p. 57-107. In: O.L. Lange, P.S. Nobel, C.B. Osmond, and H. Ziegler (eds.). Physiology of plant ecology I. Encyclopedia of plant physiology. New series, vol. 12A. SpringerVerlag, Berlin.

Boivin, C., M.J. Trudel, and A. Gosselin. 1986. Influence duniveau d'irradianced'appoint (HPS) en pépinière sur la croissance et la productivité d'une culture de tomate de serre. Can. J. Plant Sci. 66(4):961-970.

Conseil des Productions Végétales du Quebec. 1982. Légumes: Culture. Production Guide, Conseil des Productions Végéales du Québec. Agdex 250/20. Ministère de L'Agriculture, des Dêheries et de L' Alimentation, Quebec,

Desjardins, Y., A. Gosselin, and M, Lamnarre. 1990. Growth of transplants and in vitro-cultured clones of asparagus in response to $\mathrm{CO}_{2}$ enrichment and supplemental lighting. J. Amer. Soc. Hort. Sci. 115:364-368.

Little, T.M, and F.J. Hills. 1978. Agricultural experimentation: Design and analysis. Wiley, New York.

Madsen, E. 1973. The effect of $\mathrm{CO}_{2}$ concentration on development and dry matter production in young tomato plants. Acts Agr. Stand. 23(4):235-240.

Masson, J., N. Tremblay, and A. Gosselin. 1991a. Nitrogen fertilization and HPS supplementary lighting influence vegetable transplant production. I. Transplant growth. J. Amer. Soc. Hort. Sci. 116:594-598,

Masson, J., N. Tremblay, and A. Gosselin. 1991b. Effects of nitrogen fertilization and HPS supplementary lighting on vegetable transplant production. H. Yield. J. Amer. Sot. Horc. Sci. 116:599-602.

Morgan, J.V. 1971. The influence of supplementary illumination and $\mathrm{CO}_{2}$ enrichment on the growth, flowering and fruiting of the tomato. Acta Hort. 22:187-199.

Morgan, J.V. 1986. Chemical and environmental control of growth during propagation of tomato plants for transplanting. Acta Hort. 190523-530.

Mortensen, L.M. and R. Moe. 1983. Growth responses of some greenhouse plants to environment. VI. Effect of $\mathrm{CO}_{2}$ and artificial light on growth of Chrysanthemum morfolium Ramat. Scientia Hort. 19(1/2):141-147.

Porter, MA. and B. Grodzinski. 1985. CO enrichment of protected crops. Hort. Rev. 7:345-398.

Weston, L.A. and B.H. Zandstra. 1986. Effect of root container size and location of production on growth and yield of tomato transplants. J. Amer. Soc. Hort. Sci. 111:498-501. 